\title{
Rise and Fall of Interest Rates
}

\author{
NORMAN N. BOWSHER
}

M ARKET interest rates have moved over a wide range since mid-1979. In the last half of 1979 and in the first three months of 1980 , interest rates rose to unprecedented levels. Rates on highest grade corporate bonds, for example, increased from 9.3 percent in June 1979 to 13 percent in March 1980. Over the same period, yields on 4 -month prime commercial paper jumped from 9.7 percent to 16.8 percent, while the prime rate on business loans at large banks rose from 11.5 percent in mid-1979 to 20 percent in early April 1980.

Because credit and interest rates play a crucial role in our economic system, the substantial rise in interest rates had wide implications. Sales of residential housing, which are particularly sensitive to interest rate movements due to the existence of usury rate ceilings in many states, were sharply curtailed. For those business activities that maintained operations, costs rose, in some cases substantially. In fact, some analysts believe that higher interest rates were a major cause of recession. ${ }^{1}$ On the other hand, savers received record high returns on funds lent.

1"A Carter Recession: How Soon, How Deep?" U.S. News and World Report (March 31, 1980), pp. 23-29; "The Credit Vise Tightens," Time (April 14, 1980), pp. 78*79; and "High Interest Rates Start to Hit Hone," U.S. News and World Report (March 24, 1980), pp. 23-24.
A marked reversal has occurred in the financial markets since early April 1980. Highest grade corporate bond yields decreased from 13 percent in March to 12 percent in September, and yields on commercial paper fell from 16.8 percent to 10.9 percent. Large banks lowered the rate charged on loans to prime business customers from 20 percent in early April to 13 percent in late September.

Since the decline in interest rates occurred at a time when the country was facing two serious domestic economic problems - continued rapid inflation and rising unemployment - there were disparate opinions about its desirability. Some argued that the lower interest rates would stimulate business and consumer spending, while others contended that the campaign to resist inflation and to defend the value of the dollar internationally was being abandoned too soon..$^{2}$

This article attempts to place the recent fluctuations in interest rate levels into perspective by discussing both the function of interest rates and the economic significance of their levels. In addition, it reviews recent developments that impinge on interest rates.

"See "Inflation-Fighting Must Be No. 1 Priority Despite Deepening Slump, Miller Insists," Wall Street Journal, June 5, 1980, p. 8 . 


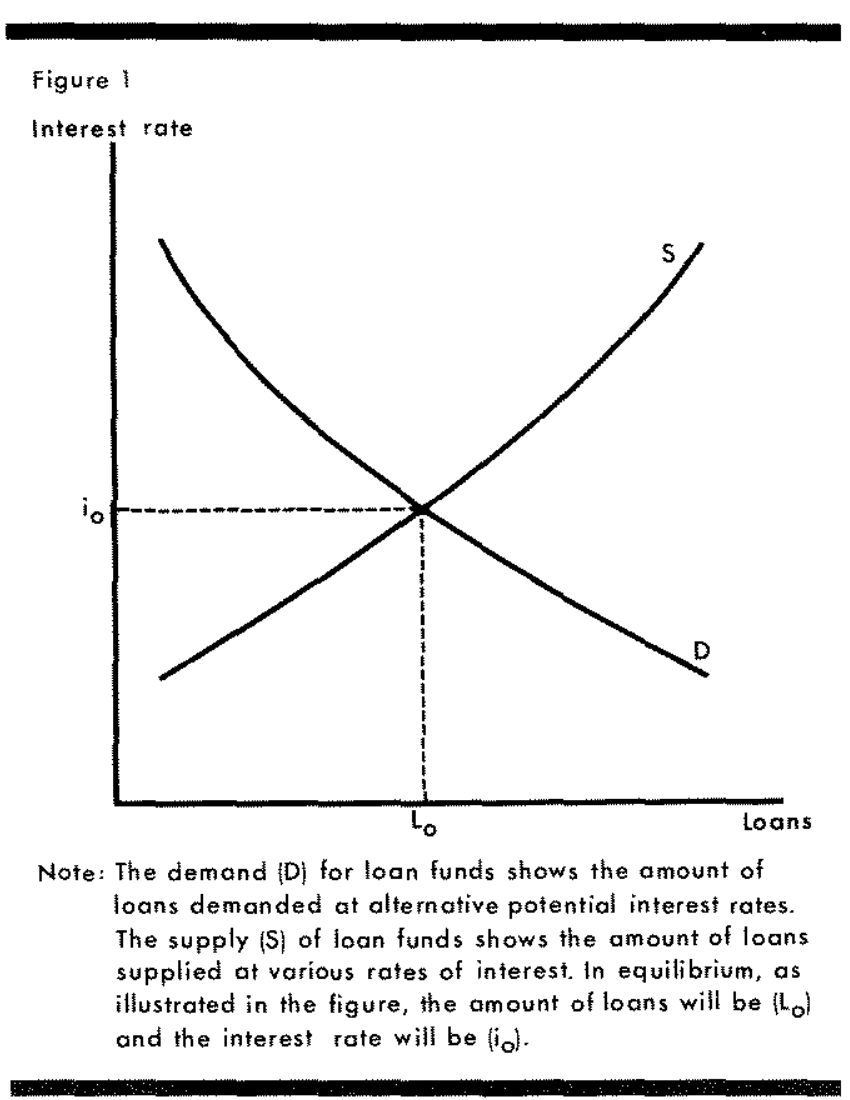

\section{Interest Rates - Real and Nominal}

The rate of interest, which represents the price paid for the use of credit, reflects the interaction between the supply of credit and the demand for credit (figure 1).$^{3}$ The supply of credit arises from the willingness of income-earners to save, that is, to postpone consumption in the immediate period. The demand for credit arises from private business firms' investment demand (reflecting the marginal productivity of real capital goods), consumers' desire to borrow for consumption purposes, and government borrowing to finance deficits.

Hundreds of different interest rates are quoted simultaneously in financial markets, These nominal (or market) interest rates, although different from one another, consist of the same three components: the "real" rate of interest, the expected rate of inflation, and a composite of the additional factors which differentiate one yield from another.

The real rate of interest is determined by the marginal productivity of capital in a "riskless" economic

3 For a more extended discussion of interest rates, see Armen A. Alchian and William R. Allen, University Economics (Belmont, Califomia: Wadsworth Publishing Company, 1972) pp. $426-438$. environment. It is the rate of interest that would be observed if inflation was expected to be zero and if there were no special differences (risk, tax advantages, etc.,) among various credit transactions. During the last century, the real rate of interest has generally moved within a rather limited range.

Special terms and conditions accompanying the extension of credit will produce differences among nominal interest rates. Differences in rates due to this source reflect variations in financial risk, length of loans, locality, costs of servicing, tax status, and a variety of other factors.

Because of inflation and inflationary expectations, the market rate of interest can differ considerably from the real rate. ${ }^{4}$ This differential exists because lenders seek to protect the purchasing power of funds lent, and borrowers are willing to pay a higher rate if they expect inflation to enable them to repay the loan with cheaper dollars.

For example, if borrowers and lenders anticipate a 9 percent inflation per year over the period of the loan, they will incorporate this expectation in the nominal rate of interest for the loan. Thus, if the real interest rate is 3 percent, loans will be extended at an annual nominal rate of 12 percent; that is, the 9 percent anticipated inflation will be added to the 3 percent real return.

Studies suggest that market participants tend to extrapolate past experience to estimate future rates of inflation. Although they place primary emphasis on the most recent past, they will reach back several years for evidence. ${ }^{5}$ Regardless of past experience, however, a substantial change in monetary or fiscal policy will alter expectations of future inflation. ${ }^{6}$ Charts 1 and 2 illustrate the relationship between prices and market interest rates for the periods 1972 1980 and 1960-1980, respectively.

Most of the increase in market interest rates since the mid-1960s resulted from rising inflationary expectations. From 1959 to 1965 , annual inflation, as measured by the GNP price deflator, averaged 1.5 percent.

4David H. Resler, "The Formation of Inflationary Expectations," this Review (April 1980), pg. 2-12. Also, see "Inflation's Impact on Borrowers and Lenders," U.S. News and World Report (March 10, 1980), p. 28.

"See Irving Fischer, The Theory of Interest (New York: Macmillan, 1930); and William P. Yohe and Denis S. Kamosky, "Interest Rates and Price Level Changes 1952-69," this Review (December 1969), pp. 18-36.

Gharles Pigott, "Expectations, Money, and Forecasting of Inflation," Federal Reserve Bank of San Francisco Economic Review (Spring 1980), pp. 30-49. 


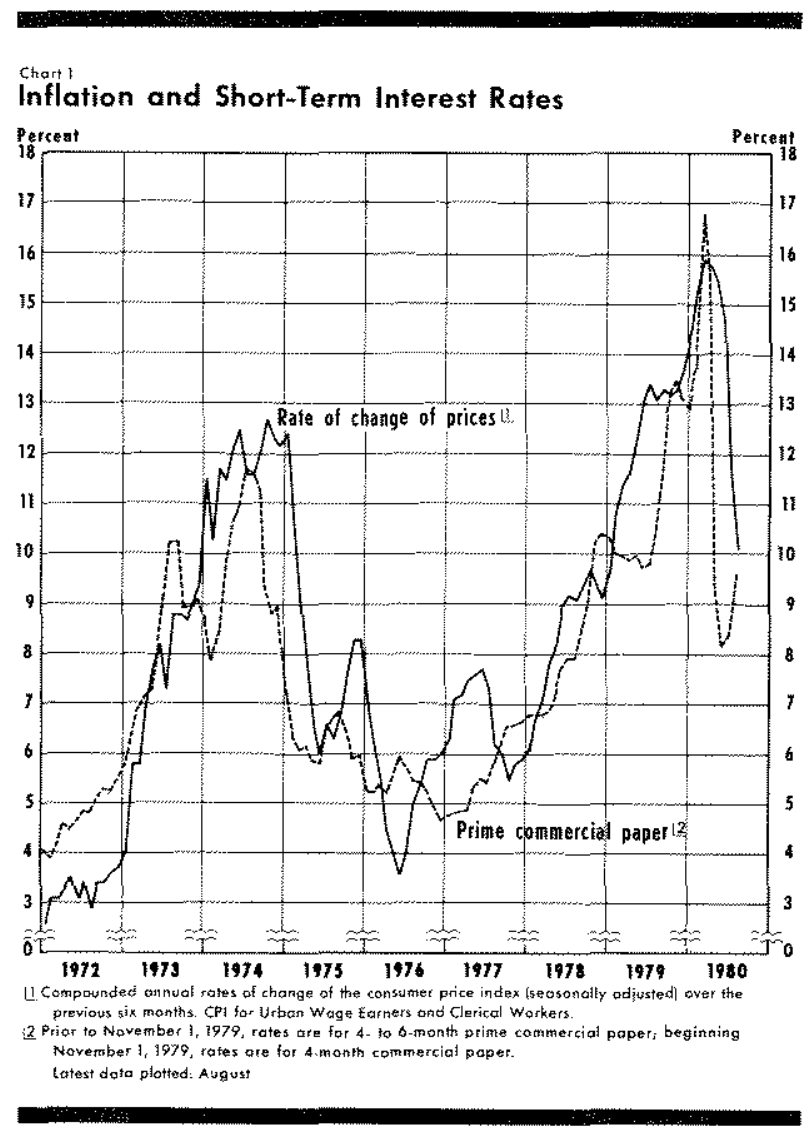

If expectations of inflation were based closely on previous actual rates, the expected rate of inflation in the mid 1960 s was approximately 1.5 percent. In contrast, from 1973 to early 1980 , the GNP price deflator rose at nearly an 8 percent rate, and, in view of the 13 percent rates of increase in both consumer and producer prices in the 18 months ending March 1980 , long-run inflationary expectations were probably in the 9 to 10 percent range in early 1980. The accelera tion of price increases in late 1979 and early 1980 led to even higher short-run inflationary expectations at the end of March 1980.

\section{Functions of Interest Rates}

Interest rates serve a number of significant functions. First, they provide investors with a guide for allocating funds among investment opportunities. As funds are directed into projects that have higher expected rates of return (risk and other factors taken into account), the funds are optimally allocated from the viewpoint of both consumer and investor, since highest returns prevail where effective consumer demand is strongest. Unless an investment opportunity promises a return high enough to pay the market rate of interest, it does not justify the required capital outlay. The money market, by channeling funds into projects that have an expected return in excess of the interest rate, provides a valuable service to investors, borrowers, and society as a whole.

The interest rate also provides a measure of the relative advantage of current consumption compared to saving. By adjusting the available market rate for expected inflation and taxes, an individual can determine the real amount of additional future consumption that can be obtained by postponing current consumption.

Similarly, interest rates help businessmen decide among afternative production methods. Suppose a product can be made either solely with labor or with a combination of labor and machinery. By calculating the capital cost of the machine (the interest rate times the dollar amount invested in the machine), the expected labor-plus-capital cost can be compared with the labor-alone cost to determine the less expensive means of production.

Finally, interest rates that are free of legal restrictions can respond to changing demand/supply situations and, thus, contribute to economic resiliency and high employment. If, for example, a government 


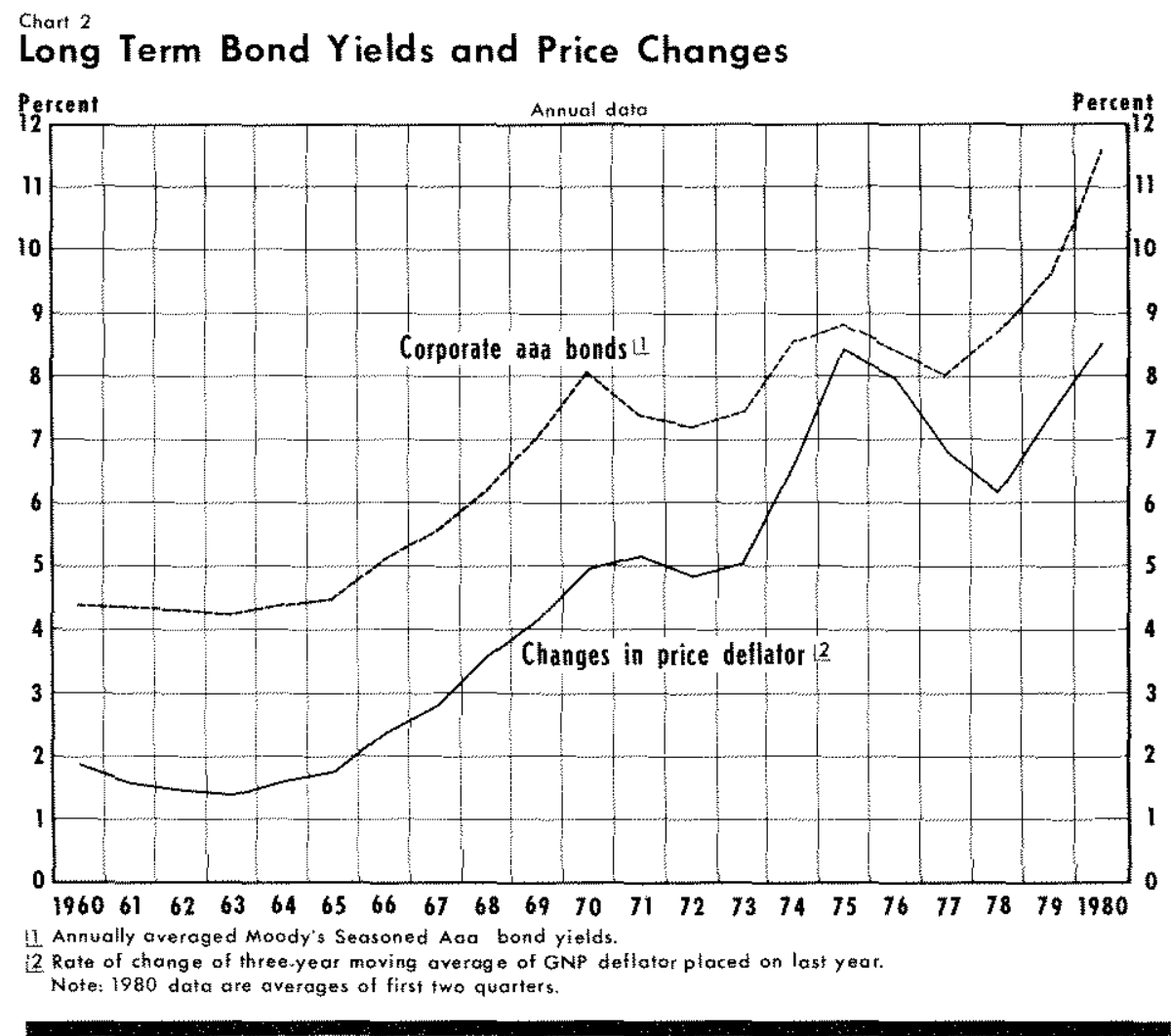

spending program is trimmed, the initial result will be unemployment and idle factories. Everything else being equal, however, reduced government spending will eventually lead to less government borrowing and lower nominal interest rates. At these lower rates, more funds will be demanded by the private sector, thus generating increased private sector jobs.

\section{Major Factors Influencing Interest Rates}

As pointed out above, interest rates are determined by the demand for and supply of credit, both of which are affected by specific factors. As these factors change, interest rates change accordingly. The more important factors include saving, business and consumer investment, monetary actions, government defcits or surpluses, and income tax rates.

Saving is the source of credit and, consequently, the amount of savings is one of the prime determinants of the level of real interest rates. As saving increases, downward pressure is exerted on interest rates. Conversely, as individuals and businesses save less, or actually dissave, upward pressure is exerted on interest rates.

Financing business inventories and capital investment constitutes a major credit demand and, because this demand is quite variable, it contributes materially to changes in interest rates. When economic activity is expanding and the outlook appears favorable, businesses aggressively seek more funds to finance additional production, plants, and equipment. On the other hand, when sales are sluggish and the future seems grim, investment plans are sharply curtailed and the demand for credit falls.

Similarly, consumers demand a substantial amount of credit to finance homes, automobiles, and other durable goods as well as to increase current consumption. This demand for credit also fluctuates widely as business conditions and the economic outlook change and, therefore, contributes significantly to interest rate movements.

Governments can either supply credit by running surpluses or demand credit to finance operating deficits. Since federal government expenditures have exceeded receipts in every fiscal year since 1969 , the government has become a large demander of credit, contributing to upward pressure on interest rates. In contrast, the federal government operated at a surplus during the mid-1920s and despite expanding business investment in that period, interest rates drifted lower on balance. 
Expansions or contractions in the stock of money, for example, can temporarily influence real interest rates and permanently affect nominal market rates. If the Federal Reserve System expands the supply of money and bank credit faster than borrowers and lenders anticipate, the additional loan funds temporarily drive both market and real interest rates below what they otherwise would have been. If rapid monetary expansion continues, it will eventually be entirely reflected in a higher rate of inflation and a higher level of nominal interest rates.

People make economic decisions by taking into account all available information that has a significant bearing on the future consequences of their decisions. Hence, in recent years, it is likely that investors and savers began anticipating the longer-run impacts of monetary actions on interest rates sooner than they did in previous periods of marked and sustained change in the growth of monetary aggregates. ${ }^{7}$

Income tax considerations also influence market interest rates. ${ }^{8}$ Since borrowers are allowed to deduct interest payments in computing taxable income, the more relevant after-tax cost of funds is less than the stated contract rate. Lenders must include interest received as taxable income, making their after-tax return less than the contract rate. Therefore, income tax causes market rates to be higher than they would be otherwise. As market interest rates have increased in recent years along with rising inflationary expectations, the absolute impact of taxes has also risen greatly. An example will help clarify this fact.

Assume that federal and state income taxes have placed both the borrower and the lender in the 50 percent marginal bracket. If, as in the early 1960s, market rates were 5 percent, income taxes reduced the return by 2.5 percentage points, leaving a 2.5 percent after-tax interest rate. More recently, as market rates fluctuated around 14 percent, income taxes reduced the return to 7 percent, leaving a 7 percent after-tax yield.

In the mid-1960s, the after-tax real interest rate was about 1 percent (based on a market rate of 5 percent, less assumed inflationary expectations of $1 \frac{1 / 2}{\text { percent }}$

\footnotetext{
${ }^{7}$ See "Rational Expectations - Fresh Ideas That Challenge Some Established Views of Policy Making," Federal Reserve Bank of Minneapolis Annual Report 1977, pp, 1-13; and Thomas I. Sargent, "A Classical Macroeconomic Model for the United States," Journal of Political Economy (April 1976), pp. 207-37.

8John A. Tatom and James E. Turley, "Intlation and Taxes: Disincentives for Capital Formation," this Review (January 1978), pp. $2-8$.
}

and a $2^{1 / 2}$ percentage point tax liability). Despite the sharp rise in market rates to 14 percent in early 1980 , the after-tax real interest rate was lower than the mid1960 rate and even negative. Assuming inflationary expectations of 9 percent per year and a tax bite of 7 percentage points, the 14 percent market interest rate implies a negative 2 percent after-tax real retum. ${ }^{9}$ As the demand to borrow increases and the supply of credit falls, interest rates tend to surge upward until the expected real rate is positive.

\section{Analysis of Interest Rate Rise - Late 1979, Early 1980}

Market interest rates, although already high relative to most previous periods in this century, rose sharply from mid-1979 to early April 1980. For example, threemonth treasury bill yields averaged 5 percent in 1976, 5.3 percent in 1977, and 7.2 percent in 1978. By June 1979 , the yield was 9.1 percent but, by early April 1980, it had jumped to 14.8 percent. Virtually all other interest rates also recorded sharp increases in the late 1979-early 1980 period, with the increase being more pronounced for shorter-term than for longer-term maturities. Many forces combined to drive up yields.

Although personal income continued to rise in late 1979 and early 1980, personal saving declined substantially in that period, placing strong upward pressure on rates. In the first six months of 1979 , personal saving grew at an $\$ 83$ billion annual rate; in the last six months of 1979 , it declined to a $\$ 65$ billion rate; and in the first quarter of 1980 , it again decreased to a $\$ 64$ billion rate. This decline in personal saving occurred for a number of reasons. Tax burdens rose more sharply than income, and inflation rapidly increased the cost of most consumer goods. With expectations of future prices being revised upward, the incentive to consume immediately was strengthened.

In this same period, investment in business plants, equipment, and inventories and in residential structures increased slightly on balance, creating an additional small upward pressure on rates. In the aggregate, gross private domestic investment inched up from a $\$ 385$ billion annual rate in the first half of 1979 to a $\$ 390$ billion rate in the last half, and then drifted to a $\$ 388$ billion rate in the first quarter of 1980. Fixed business investment rose, but this was

\footnotetext{
9Tom Herman, "Even Today's Steep Interest Rates Appear Low if "Taxes and Inflation Are Taken Into Account," Wall Street Journal, April 3, 1980, p. 40.
} 
largely offset by cutbacks in housing and in inventory growth.

Both saving and investment decisions were heavily influenced by accelerated inflation and inflationary expectations. Consumer prices, for example, rose at an average 4.3 percent annual rate from 1960 to 1977 , 7.7 percent in $1978,11.3$ percent in 1979 , and 18.1 percent in the first quarter of 1980 . The rates of increase for producer prices were 3.9 percent, 7.8 percent, 10.9 percent, and 19.3 percent, respectively.

The marked increase in inflation during 1979 reflected both monetary and nonmonetary factors. From the third quarter of 1976 to the third quarter of 1979 , the money stock rose at an average 8.3 percent annual rate compared with a 5 percent rate in the previous three years. This acceleration in monetary expansion caused an increase in the trend rate of inflation. Moreover, strong forces pushed the current measured rate of inflation considerably above the trend rate during 1979 and early 1980. Chief among these forces was a substantial increase in the price of oil by OPEC, which caused a major rise in the cost of energy and, in turn, placed large cost-push pressures on many other prices.

Federal govemment deficits increased in late 1979 and early 1980, placing further upward pressure on rates. Deficits, as recorded in the national income accounts budget, rose from an annual rate of $\$ 9.4$ billion in the first half of 1979 to $\$ 12.7$ billion in the second half and to $\$ 22.9$ billion in the first quarter of 1980 .

In early October 1979 , the Federal Reserve announced that it would provide only enough money to accommodate production at a gradually reduced rate of inflation. The uncertainty about how this new monetary policy would be implemented contributed to higher market interest rates for a time. Previously, from the third quarter of 1976 to the third quarter of 1979 , money (M1B) had risen at an 8.3 percent annual rate. Then, from the third quarter of 1979 to the first quarter of 1980 , money growth slowed to a more moderate 5.6 percent pace. In March and April 1980 , money actually contracted. The short-run impact of the reduced money growth followed by the actual decline in money was a reduced supply of credit, which placed additional strong upward pressure on interest rates.

\section{Analysis of Interest Rate Decline - After Early April 1980}

The financial "crunch" ended in early April 1980. Interest rates, which had been rising sharply, sud- denly began falling. The three-month Treasury bill yield, which was 14.8 percent in early April, averaged 10.3 percent in September. Other rates followed a similar course and, again, securities with the shortest maturities showed the widest movement.

One of the chief underlying factors responsible for this reversal was the lagged effects of the new monetary policy that was announced in early October 1979. This policy caused money to expand at a slower rate and, initially, placed upward pressure on rates because credit growth slowed. However, the secondary and more powerful effects of this action offset its initial impact after a few months.

One delayed result of supplying money to the market at a gradually slower rate was a dampening of economic activity. With less money being supplied, relative to the demand to hold money, spending gradually moderated. Nevertheless, credit demand continued strong for a time because consumers and businesses were uncertain about how long the pause in spending would continue and how long the Federal Reserve would continue to restrain money growth. As sales, production, and employment began falling, demand for business and consumer credit sharply declined.

Another result of the new monetary policy was its delayed effect on inflationary expectations. Since the rate of inflation is largely determined by the average rate of growth of money over the previous five years, the first few months of a new rate of money expansion has little effect on the five-year average growth trend and, hence, little effect on actual inflation. Moreover, since in the current situation there was uncertainty as to how long the Federal Reserve would maintain the more moderate money growth in view of the rapidly rising interest rates and the expansionary federal budget announced in January 1980, there was little or no downward revision of future inflationary expectations. ${ }^{10}$ The February to April 1980 money contraction, however, changed the situation dramatically. Since market participants began to believe that significant steps were being taken to reduce inflation (evidenced by the continued restraint on money growth despite the business downturn and extremely high interest rates), future inflationary expectations diminished.

In mid-March, the government imposed a number of credit controls to restrain credit demand. Since they applied to many new areas (e.g., credit cards

10The Kiplinger Washington Letter, February 1, 1980. 
and money market funds), they were poorly understood. In addition, they were untimely because they were imposed just after the economy began an economic downturn. These controls, combined with other developments, caused consumers to reduce credit demands further which, in turn, contributed to the fall of interest rates after early April 1980.

With inflation still intensifying and interest rates rising in the first quarter of 1980 , the Administration and many members of Congress felt that it was mandatory that the government follow a less expansive fiscal policy and, consequently, efforts were made to present a "balanced" budget. Although most analysts still felt that expenditures would continue to exceed receipts in fiscal 1980 and 1981, the concern of public officials and their announced intentions to trim out lays contributed to a reduction in inflationary expectations and in interest rates. ${ }^{11}$

\section{Interest Rates as a Measurement of Monetary Action}

Market interest rate levels and movements have been used as guides to monetary actions, particularly by financial commentators and participants in money and capital markets. ${ }^{12}$ High and rising market interest rates generally reflect monetary restriction, whereas low and declining rates indicate monetary ease. However, market interest rates may be rising while the real rates are falling, and it is the real rates that are important in terms of economic activity. Expansions or contractions of money and credit can force the real interest rate, as well as the market rate, to rise and fall, at least temporarily. Such changes in interest rates influence the cost of investing and, hence, the course of economic activity.

Notwithstanding, it is virtually impossible to isolate and interpret the effects of monetary actions on market interest rates. Not only are investment deci-

\footnotetext{
11The Kiplinger Washington Letter, March 21, 1980.

${ }^{12}$ At times, the Federal Reserve System has also used interest rates as a measure of monetary action. For example the 66th Annual Repont of the Board of Governors of the Federal Reserve Systen states that, "Monetary policy in 1979 sought to curb intationary pressures. . . Early in the year, when ... incoming economic data provided some indications of softening in economic activity, the Federal Reserve avoided meas. ures that would have led to a marked rise in interest rates or would have severely reduced the availability of credit. But expenditures for goods and services strengthened as the year progressed, in part because of heightened inflationary expectations. Consequently, the System adopted a progressively less accommodative stance, allowing the federal funds rate to rise and increasing the discount rate in several steps." Board of Covernors of the Federal Reserve System 66th Annual Report, 1979 , p. 14.
}

sions and saving/consumption choices (among other factors that influence interest rates) in constant flux, but monetary actions themselves have an ambiguous impact on rates due to the various lagging effects of these actions. ${ }^{13}$

If the stock of money is expanded unexpectedly, for example, the supply of available funds is augmented, real and nominal interest rates are initially depressed, and the economy is thereby stimulated. If the new course of rapid monetary expansion is continued for approximately a year, further stimulative effects on total demand will occur. At the same time, however, inflation and interest rates will also begin to move upward. If the same rate of money injection is followed for approximately five years, the effects of this expansive monetary action will be fully reflected throughout the economy. Interest rates will have reached a level which exactly reflects the real rate plus the long-run expected rate of inflation. Continuation of the faster monetary growth would have no further effects on real economic activity or the rate of increase of the price level.

Since, at any one time, market interest rates reflect the monetary actions taken over various past periods, they have been a less reliable guide to monetary actions than rates of growth of the monetary aggregates. ${ }^{14}$ More often than not over the past 60 years, when monetary expansion has been relatively rapid long enough to stimulate economic activity, interest rates have risen rather than declined. The chief reason is that inflation and inflationary expectations also increase when monetary expansion is substantial enough to drive the economy at a quicker pace. The greater activity and the revised inflation outlook raise the demand for credit even faster than the monetary expansion increases the supply. Similarly, when monetary contraction is continued for more than a few months, interest rates usually fall - not rise - since the monetary contraction eventually causes an even larger decline in credit demand by depressing total nominal demand for goods and services.

From this analysis, it can be concluded that from the third quarter of 1976 to the third quarter of 1979 monetary actions were expansive because money was increasing at a relatively rapid rate. During this pe-

\footnotetext{
13 Michael I. Hamburger, "The Lag in the Effect of Monetary Policy: A Survey of Recent Literature," Monetary Aggregates and Monetary Policy, Federal Reserve Bank of New York (October 1974), pp. 104-113.

${ }^{14}$ William Poole, "Optimal Choice of Monetary Policy Instruments in a Simple Stochastic Macro Model, Quarterly Joutnal of Economics (May 1970), pp. 197-216.
} 
riod, business activity increased and inflation intensified in response to the monetary stimulus. The higher interest rates reflected the greater economic activity and rising inflationary expectations that the monetary expansion fostered.

From the third quarter of 1979 to February 1980, monetary actions, as measured by money growth, gradually became less expansive. Since interest rates rose in this period, the two measures of policy temporarily gave similar signals of restraint as they frequently do around cyclical turning points in business activity.

From February to June 1980 , money contracted an indication that monetary actions were extremely restrictive. Until early April, interest rates continued to increase but then fell sharply, indicating to some people that a shift toward monetary ease had occurred. Business activity, however, declined sharply and inflation slowed after the first quarter of 1980 . This decline in business activity and some downward revision in inflationary expectations were largely re sponsible for the fall in market interest rates.

\section{Conclusions}

Market interest rates have been moving gradually upward since 1976. One principal cause of the rise in rates over the longer period was an upward revision in inflationary expectations caused both by monetary developments and by an increase in oil prices by the international cartel. In addition, income tax implications for both borrower and lender and the continuously heavy borrowing by the government to finance operating deficits contributed to higher yields.
From mid-1979 to the end of March 1980, interest rates surged to unprecedentedly high levels. The main reasons for this rise were the slowing of money growth by the Fed, the acceleration in private borrowing (perhaps in anticipation of credit control restrictions), and the increase in government borrowing.

From September 1979 to June 1980, money (M1B) expanded at an average 3 percent annual rate, down from the rapid 8 percent average of the previous three years. Such a marked and sustained slowing in monetary growth temporarily placed strong upward pressure on interest rates. As the effects of this slower money growth were reflected in reduced spending and as the public gained confidence that a slower growth path for money might be continued, inflation and inflationary expectations began to recede. These developments, combined with the imposition of the credit restraints, caused market rates to fall abruptly after early April 1980.

A marked shift in monetary policy toward restraint, such as the one that occurred from September 1979 to June 1980, has mixed implications for the economy and future interest rates. On the one hand, the expected rate of inflation is reduced, at least temporarily. In addition, economic activity is depressed much more drastically during the transition to more stable prices than it would be if money growth were slowed gradually. This dramatic decline in economic activity pushes down interest rates. On the other hand, the lower sales, production, and employment during the adjustment period increase the chances that high monetary growth may be resumed and inflation may accelerate in the future. This would lead to an increase in interest rates.

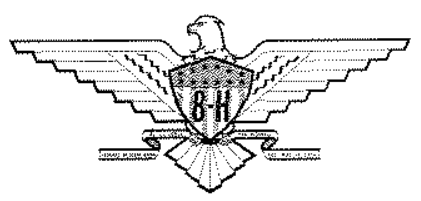

